\title{
Development of High Strength 15Cr Ferritic Creep Resistant Steel with Addition of Tungsten and Cobalt
}

\author{
Kazuhiro KIMURA', Kazuhiro SEKI ${ }^{2)}$, Yoshiaki TODA ${ }^{1)}$ and Fujio ABE ${ }^{1)}$ \\ 1) Frontier Research Center for Structural Materials, National Research Institute for Metals, \\ 1-2-1 Sengen, Tsukuba-shi, Ibaraki 305-0047 Japan \\ 2) Interdisciplinary Graduate School of Science and Engineering, Tokyo Institute of Technology, \\ 4259 Nagatsuta, Midori-ku, Yokohama, Kanagawa 226-8502 Japan
}

\begin{abstract}
Effects of alloying elements of $W$ and $C o$ on a creep strength of full annealed $15 \mathrm{Cr}$ ferritic steel whose chemical composition is $\mathrm{Fe}-0.1 \mathrm{C}-15 \mathrm{Cr}-1 \mathrm{Mo}-3 \mathrm{~W}-0.2 \mathrm{~V}-0.05 \mathrm{Nb}-0.07 \mathrm{~N}-0.003 \mathrm{~B}$ has been investigated. Increases in creep strength with increase in $\mathrm{W}$ content and addition of Co have been obviously observed. About 10 times and 30 times longer time to rupture than that of the base steel have been obtained at $923 \mathrm{~K}-100 \mathrm{MPa}$ by increase in W content from 3 mass $\%$ to 6 mass $\%$ and addition of 3 mass $\%$ of Co, respectively. Moreover, significant improvement of creep strength has been observed by the combination of increase in $\mathrm{W}$ content and addition of $\mathrm{Co}$. Time to rupture of the steel strengthened by 6 mass $\%$ of $W$ and 3 mass $\%$ of Co is 100 times longer than that of the base steel at $923 \mathrm{~K}-100 \mathrm{MPa}$. Creep rupture strength of the steel containing 6 mass $\%$ of $W$ and 3 mass $\%$ of Co is almost the same as that of ASME T92 steel. Since $\mathrm{Cr}$ content of conventional ferritic creep resistant steels is less than 12 mass $\%$, oxidation resistance of the $15 \mathrm{Cr}$ ferritic steel investigated in this study is better than those of conventional ferritic creep resistant steels. It has been concluded that a full annealed $15 \mathrm{Cr}$ ferritic creep resistant steel should be one of the candidate materials for new Ultra Supercritical (USC) power plant in the 21st century.
\end{abstract}

KEY WORDS: $15 \mathrm{Cr}$ ferritic steel; creep; ferritic creep resistant steel; high strength; precipitation strengthening; USC power plant.

\section{Introduction}

Since a main source of $\mathrm{CO}_{2}$ emission in Japan is a combustion of huge amounts of oil, coal and natural gas in the fossil fired power plant, improvement of energy efficiency is one of the most important problem in electrical power generation. And reliability of high temperature components should be also certified to maintain a stable supply of electricity without accident. Consequently, a lot of efforts have been done to develop a new high strength ferritic creep resistant steel that is available for large components of fossil fired power plants ${ }^{1-3)}$

Because microstructure is unstable at elevated temperatures, long term creep strength of the material is strongly influenced by degradation during long term exposure at the elevated temperatures. Creep rupture strength of many types of ferritic creep resistant steels are shown in Fig.1. Large differences in creep rupture strength are observed in the short term region. However, all the data show the tendency to converge to a common inherent creep strength of ferritic steels in the long term region. Such convergence of creep strength to a common inherent creep strength is caused by decrease in creep strength as a result of microstructural changes ${ }^{4,5)}$. Preferential recovery at a vicinity of prior austenite grain boundary and expansion of it have been pointed out as a degradation mechanism on a $1 \mathrm{Cr}-1 \mathrm{Mo}-0.25 \mathrm{~V}$ steam turbine rotor steel ${ }^{6)}$ and a modified $9 \mathrm{Cr}-1 \mathrm{Mo}$ steel ${ }^{7,8)}$. Improvement of stability of microstructure is very important to retard a degradation process and to obtain excellent long term creep strength.
On the other hand, improvement of long term creep strength may be achieved by not only stabilizing microstructure, but also strengthening of full annealed microstructure. Recently, it has been reported that the effect of initial microstructure on creep strength is clearly observed even in the very long term region as shown in Fig. $2^{9,10)}$. Long term creep rupture strength of the full annealed ferrite pearlite microstructure is higher than those of martensite, tempered martensite and bainite.

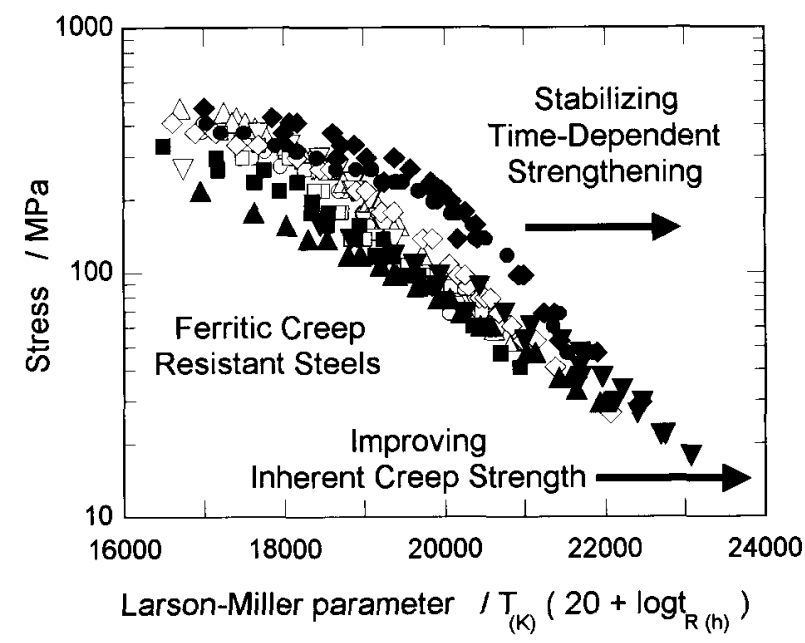

Fig. 1 Creep rupture strength properties of ferritic creep resistant steels. 


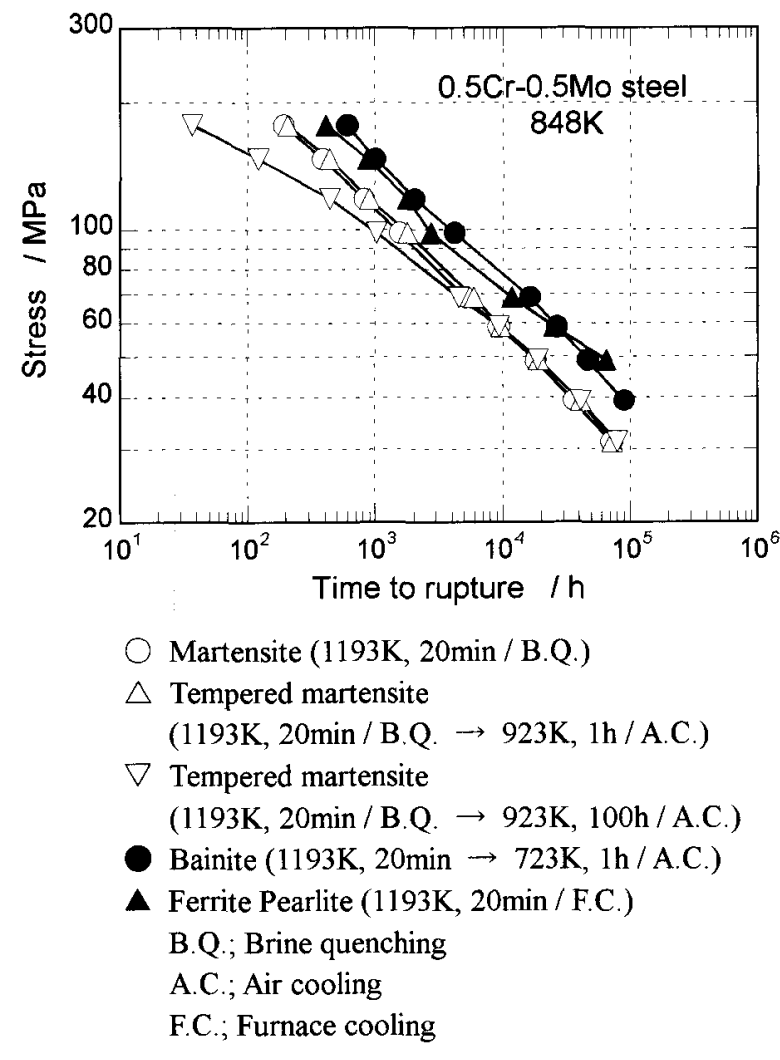

Fig. 2 Effects of initial microstructure on the creep strength property of a $0.5 \mathrm{Cr}-0.5 \mathrm{Mo}$ steel at $848 \mathrm{~K}^{9,10)}$

A $\mathrm{Cr}$ content of high $\mathrm{Cr}$ ferritic creep resistant steel is restricted to be less than about 12 mass $\%$, in order to avoid a formation of $\delta$-ferrite and to obtain a full martensite. From the results on a $0.5 \mathrm{Cr}-0.5 \mathrm{Mo}$ steel which are shown in Fig. 2, however, there is a possibility to obtain high long term creep strength by full annealed ferrite microstructure. To obtain such ferrite microstructure, higher $\mathrm{Cr}$ content than those of conventional high $\mathrm{Cr}$ ferritic creep resistant steel is suitable. Higher $\mathrm{Cr}$ content is desirable also for good oxidation resistance. In this study, consequently, improvement of creep strength through the effect of precipitation strengthening has been investigated on full annealed $15 \mathrm{Cr}$ ferritic steel.

Table 1. Chemical compositions of the steels studied. $/$ mass $\%$

\begin{tabular}{l|cccccc}
\hline & $\mathrm{C}$ & $\mathrm{Si}$ & $\mathrm{Mn}$ & $\mathrm{Cr}$ & $\mathrm{Mo}$ & $\mathrm{W}$ \\
\hline 3W-0Co & 0.110 & 0.24 & 0.49 & 15.21 & 0.98 & 2.95 \\
6W-0Co & 0.095 & 0.20 & 0.50 & 15.10 & 0.98 & 5.96 \\
3W-3Co & 0.096 & 0.20 & 0.50 & 15.11 & 0.99 & 3.01 \\
6W-3Co & 0.096 & 0.18 & 0.50 & 15.10 & 0.99 & 5.94 \\
\hline
\end{tabular}

\begin{tabular}{c|ccccc}
\hline & $\mathrm{V}$ & $\mathrm{Nb}$ & $\mathrm{Co}$ & $\mathrm{N}$ & $\mathrm{B}$ \\
\hline 3W-0Co & 0.20 & 0.051 & - & 0.071 & 0.0028 \\
6W-0Co & 0.19 & 0.059 & - & 0.083 & 0.0030 \\
3W-3Co & 0.19 & 0.060 & 3.01 & 0.083 & 0.0030 \\
6W-3Co & 0.18 & 0.064 & 3.00 & 0.082 & 0.0027 \\
\hline
\end{tabular}

\section{Experimental Procedure}

Chemical compositions of the steels investigated in this study are shown in Table 1 . Fe- $0.1 \mathrm{C}-15 \mathrm{Cr}-1 \mathrm{Mo}-3 \mathrm{~W}-0.2 \mathrm{~V}-$ $0.05 \mathrm{Nb}-0.07 \mathrm{~N}-0.003 \mathrm{~B}(3 \mathrm{~W}-0 \mathrm{Co})$ is a base composition. Effects of increase in W content from 3 mass $\%$ to 6 mass $\%$, addition of 3 mass $\%$ of $\mathrm{Co}$ and combination of those on creep strength were investigated. Steels were melted in a vacuum induction furnace. The ingots were hot forged into bars in a diameter of $13 \mathrm{~mm}$ and annealed for $30 \mathrm{~min}$ at $1473 \mathrm{~K}$ followed by furnace cooling. Creep tests were conducted at $923 \mathrm{~K}$. Microstructure was examined using by SEM and TEM.

\section{Results and Discussion}

Secondary electron images of the steels in the as annealed condition are shown in Fig. 3. Almost of the matrix are ferrite for all the steels studied, and a lot of particles are observed mainly at the grain boundary in the as annealed condition. Blocky type large particles are observed both at grain boundary and within grain in the $6 \mathrm{~W}-0 \mathrm{Co}$ and $6 \mathrm{~W}-3 \mathrm{Co}$ steels, the size and the amounts of precipitates of those steels are higher than those of the $3 \mathrm{~W}-0 \mathrm{Co}$ and the $3 \mathrm{~W}-3 \mathrm{Co}$ steels. Vickers hardness of the steels in the as annealed condition are shown in Table 2 and that of $3 \mathrm{~W}-0 \mathrm{Co}$ steel is 168 . Increases in Vickers hardness of about 30 with increase in $\mathrm{W}$ content from 3 mass $\%$ to 6 mass $\%$ $(6 \mathrm{~W}-0 \mathrm{Co})$ and about 50 by addition of 3 mass $\%$ of $\mathrm{Co}$ (3W-3Co) are observed. A significant increase in Vickers hardness of about 180 has been observed by a combination of increase in W content from 3 mass $\%$ to 6 mass $\%$ and addition of 3 mass $\%$ of $\mathrm{Co}(6 \mathrm{~W}-3 \mathrm{Co})$.

Creep rate vs. time curves of the $3 \mathrm{~W}-0 \mathrm{Co}$ steel at $923 \mathrm{~K}-120,100,80,70$ and $60 \mathrm{MPa}$ are shown in Fig.4. Creep deformation of the $3 \mathrm{~W}-0 \mathrm{Co}$ steel consists of transient and tertiary creep stages and no complex behaviour is observed. However, creep rate vs. time curves indicate a stress dependence of the creep deformation behaviour in the transient creep stage. The magnitude of decrease in creep rate in the transient creep stage increases with decrease in applied stress. Large decreases in creep rate are observed especially in the latter stage of transient creep after about $100 \mathrm{~h}$ at 70 and $60 \mathrm{MPa}$.

Bright field TEM images of the $3 \mathrm{~W}-0 \mathrm{Co}$ steel in the as annealed condition, after crept for $100 \mathrm{~h}$ and $1,000 \mathrm{~h}$ at 923K-70MPa are shown in Fig. 5 (a), (b) and (c). The precipitates are observed mainly at grain boundary and few particles precipitated within grain in the as annealed condition (Fig. 5 (a)). A small amount of particles precipitated within grain is observed after crept for $100 \mathrm{~h}$ at 923K-70MPa (Fig. 5 (b)). Precipitation of a large amount of particles within grain and formation of subboundaries are observed after crept for $1,000 \mathrm{~h}$ at $923 \mathrm{~K}-70 \mathrm{MPa}$. Development of such subboundaries is thought to be caused by many particles which act as a barrier of moving dislocation. According to such changes in microstructure from $100 \mathrm{~h}$ to $1,000 \mathrm{~h}$, a large decrease in creep rate is observed. Consequently, large decreases in creep rate observed in the latter stage of transient creep at 70 and $60 \mathrm{MPa}$ is caused by the effect of precipitation strengthening. 

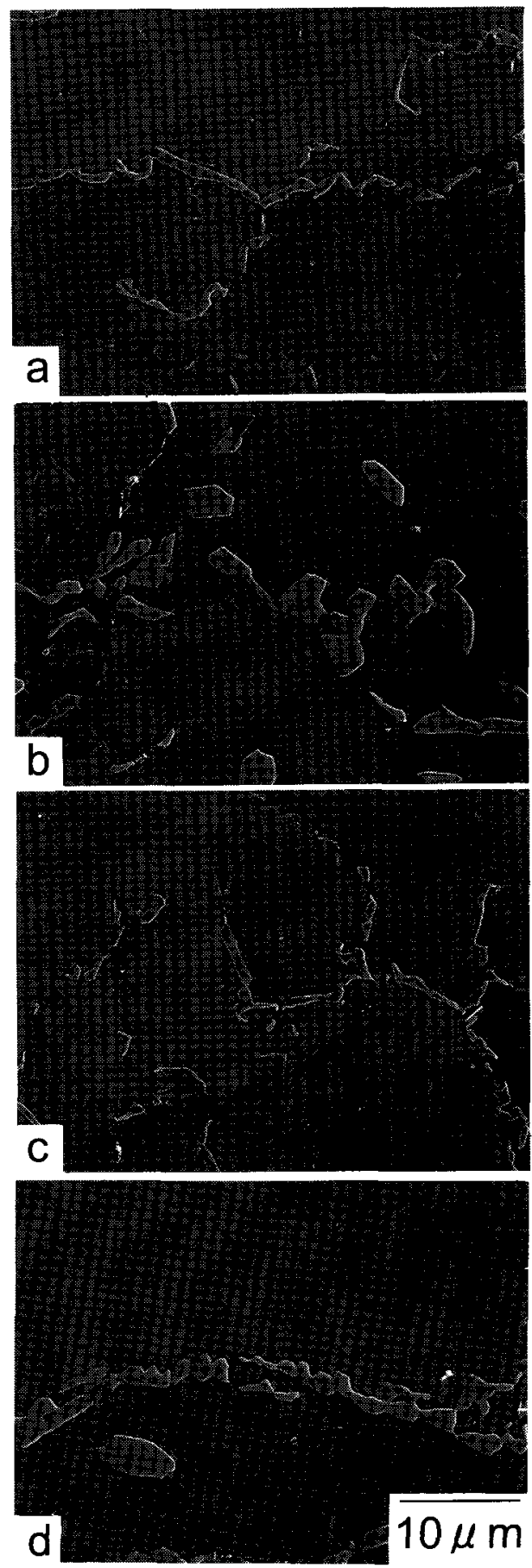

a) $3 \mathrm{~W}-\mathrm{OCo}$

b) $6 \mathrm{~W}-0 \mathrm{Co}$

c) $3 \mathrm{~W}-3 \mathrm{Co}$

d) $6 \mathrm{~W}-3 \mathrm{Co}$

Fig. 3 Secondary electron images of the steels in the as annealed condition.

Table 2. Vickers hardness of the steels as annealed condition

\begin{tabular}{cccc}
\hline $3 \mathrm{~W}-0 \mathrm{Co}$ & $6 \mathrm{~W}-0 \mathrm{Co}$ & $3 \mathrm{~W}-3 \mathrm{Co}$ & $6 \mathrm{~W}-3 \mathrm{Co}$ \\
\hline 168 & 196 & 217 & 351 \\
\hline
\end{tabular}

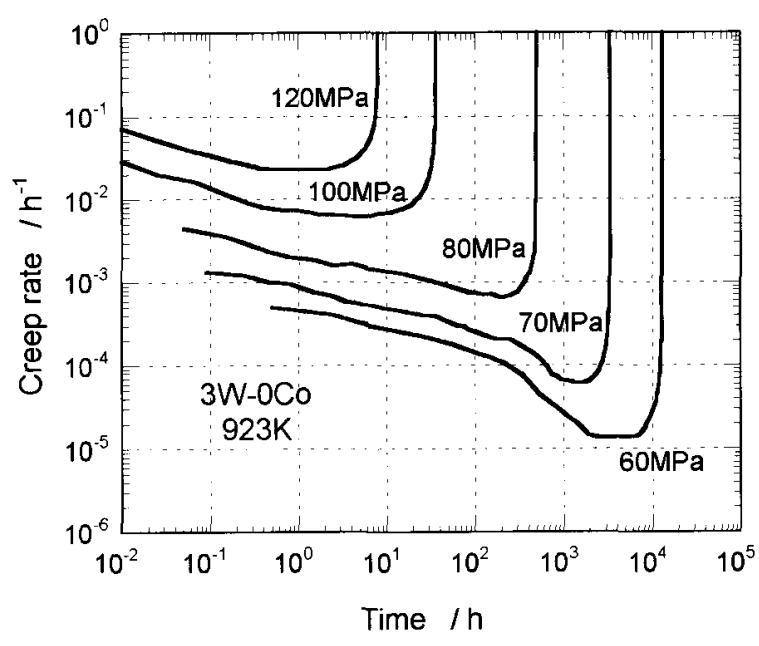

Fig. 4 Creep rate vs. time curves of the $3 \mathrm{~W}-0 \mathrm{Co}$ at $923 \mathrm{~K}$.
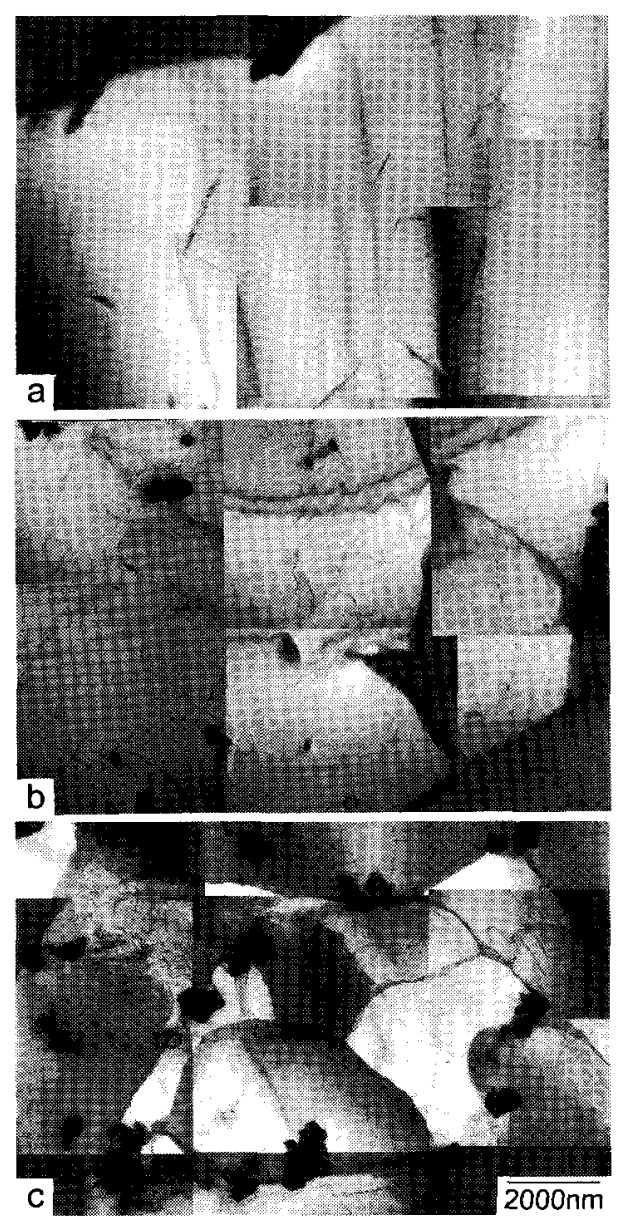

a) as annealed

b) crept for $100 \mathrm{~h}$ at $923 \mathrm{~K}-70 \mathrm{MPa}$

c) crept for $1000 \mathrm{~h}$ at $923 \mathrm{~K}-70 \mathrm{MPa}$

Fig. 5 Bright field TEM images of the $3 \mathrm{~W}-0 \mathrm{Co}$ in the as annealed condition (a), after crept for $100 \mathrm{~h} \mathrm{(b)} \mathrm{and}$ $1,000 \mathrm{~h}(\mathrm{c})$ at $923 \mathrm{~K}-70 \mathrm{MPa}$ 
Stress vs. time to rupture curves of the steels at $923 \mathrm{~K}$ are shown in Fig. 6. Increases in creep rupture strength with increase in $\mathrm{W}$ content from 3 mass $\%$ to 6 mass $\%$ and addition of 3 mass $\%$ of Co are clearly observed at $923 \mathrm{~K}$. Creep rupture lives of the $6 \mathrm{~W}-0 \mathrm{Co}$ and $3 \mathrm{~W}-3 \mathrm{Co}$ steels are about 3 times and 10 times longer than that of the $3 \mathrm{~W}-0 \mathrm{Co}$ steel, respectively. Strengthening effect of the addition of 3 mass $\%$ of $\mathrm{Co}$ is larger than that of the increase in $\mathrm{W}$ content from 3 mass $\%$ to 6 mass $\%$. Creep rupture strength at $923 \mathrm{~K}$ of the $3 \mathrm{~W}-3 \mathrm{Co}$ steel is almost the same as that of a modified 9Cr-1Mo steel (ASME T91/P91) ${ }^{11)}$. Moreover, significant increase in creep rupture strength is obtained by a combination of increase in $\mathrm{W}$ content from 3 mass $\%$ to 6 mass $\%$ and addition of 3 mass $\%$ of Co. Creep rupture life of the $6 \mathrm{~W}-3 \mathrm{Co}$ steel is about 100 times longer than that of the $3 \mathrm{~W}-0 \mathrm{Co}$ steel. and the creep rupture strength of that is almost the same as that of a NF616 (ASME T92/P92) ${ }^{12}$. Good ductility which is higher than $30 \%$ of rupture elongation is observed for all the steels studied in this investigation.

Creep rate vs. time curves of the steels at $923 \mathrm{~K}-100 \mathrm{MPa}$ are shown in Fig. 7. Creep rate of the $6 \mathrm{~W}-0 \mathrm{Co}$ steel is slightly smaller than that of the $3 \mathrm{~W}-0 \mathrm{Co}$ steel at the beginning of creep deformation, however, the magnitude of decrease in creep rate of the former steel in the transient creep stage is larger than that of the latter one, and the minimum creep rate of the $6 \mathrm{~W}-0 \mathrm{Co}$ steel is about one tenth of that of the $3 \mathrm{~W}-0 \mathrm{Co}$ steel. On the other hand, creep rate of the $3 \mathrm{~W}-3 \mathrm{Co}$ steel is about one tenth of that of the $3 \mathrm{~W}-0 \mathrm{Co}$ steel at the beginning of creep deformation, and the magnitude of decrease in creep rate in the transient creep stage is almost the same as that of $6 \mathrm{~W}-0 \mathrm{Co}$ steel. Decrease in minimum creep rate of about two orders of magnitude is obtained by the addition of 3 mass $\%$ of Co. Moreover, drastic decrease in creep rate is observed in the transient creep stage of the $6 \mathrm{~W}-3 \mathrm{Co}$ steel. At the beginning of creep deformation, creep rate of the $6 \mathrm{~W}-3 \mathrm{Co}$ steel is about one tenth of that of the $3 \mathrm{~W}-0 \mathrm{Co}$ steel, and the significant decrease in creep rate of about two orders of magnitude is observed in the transient creep stage of the $6 \mathrm{~W}-3 \mathrm{Co}$ steel.

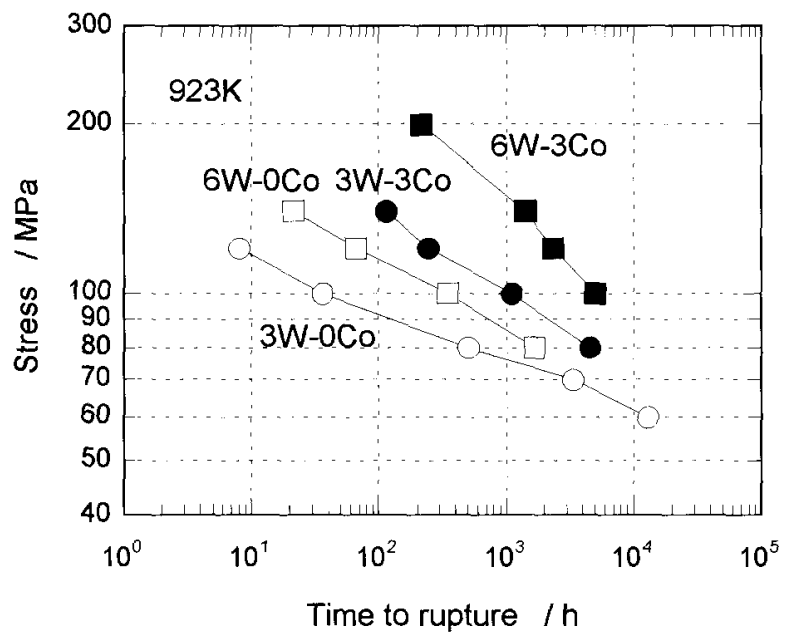

Fig. 6 Stress vs. time to rupture curves of the steels at $923 \mathrm{~K}$.
Drastic decrease in minimum creep rate of about three orders of magnitude is obtained by a combination of increase in $\mathrm{W}$ content from 3 mass $\%$ to 6 mass $\%$ and addition of 3 mass $\%$ of $\mathrm{Co}$.

From the above results, the effects of alloying elements of $\mathrm{W}$ and $\mathrm{Co}$ on the creep deformation behaviour have been summarized as follows;

(1) Increase in W content increases a magnitude of decrease in creep rate in a transient creep stage.

(2) Addition of Co decreases a creep rate at the beginning of creep deformation and increases a magnitude of decrease in creep rate in a transient creep stage.

(3) Combination of increase in W content and addition of Co decreases a creep rate at the beginning of creep deformation and drastically decreases a creep rate in a transient creep stage.

Secondary electron images of the creep ruptured specimens at $923 \mathrm{~K}-100 \mathrm{MPa}$ of (a) $3 \mathrm{~W}-0 \mathrm{Co}$, (b) $6 \mathrm{~W}-0 \mathrm{Co}$, (c) $3 \mathrm{~W}-3 \mathrm{Co}$ and (d) $6 \mathrm{~W}-3 \mathrm{Co}$ steels are shown in Fig. 8 . A slightly coarsened grain boundary precipitates are observed in the $3 \mathrm{~W}-0 \mathrm{Co}$ steel (a) creep ruptured after $36.0 \mathrm{~h}$ at $923 \mathrm{~K}-100 \mathrm{MPa}$, and there is no obvious change within grain. Although only a little change is observed on grain boundary precipitates in the creep ruptured specimens of the other three steels (b)-(d), a lot of fine particles precipitated within grain are observed, especially in the $6 \mathrm{~W}-3 \mathrm{Co}$ steel (d). Precipitation of such fine particles within grain may result in decrease in creep rate in the transient creep stage. Significant decrease in creep rate of the $6 \mathrm{~W}-3 \mathrm{Co}$ steel may be obtained by such large amounts of fine particles precipitated within grain during creep deformation. Strengthening effect of $\mathrm{W}$ and $\mathrm{Co}$ in the full annealed $15 \mathrm{Cr}$ ferritic steel is thought to be obtained by a precipitation strengthening that is mainly supported by fine particles precipitated during creep deformation. It has been concluded that creep strength of full annealed $15 \mathrm{Cr}$ ferritic steel can be improved to the same level as those of $9-12 \mathrm{Cr}$ ferritic creep resistant steel and, therefore, a full annealed $15 \mathrm{Cr}$ ferritic steel should be one of the candidate materials for new Ultra Supercritical power plant in the 21 st century.

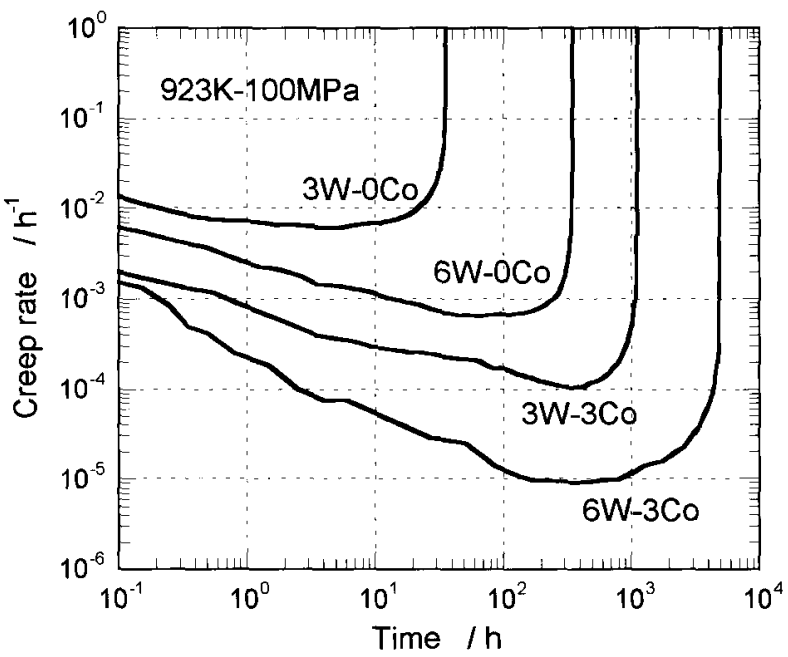

Fig. 7 Creep rate vs. time curves of the steels at 923K$100 \mathrm{MPa}$. 


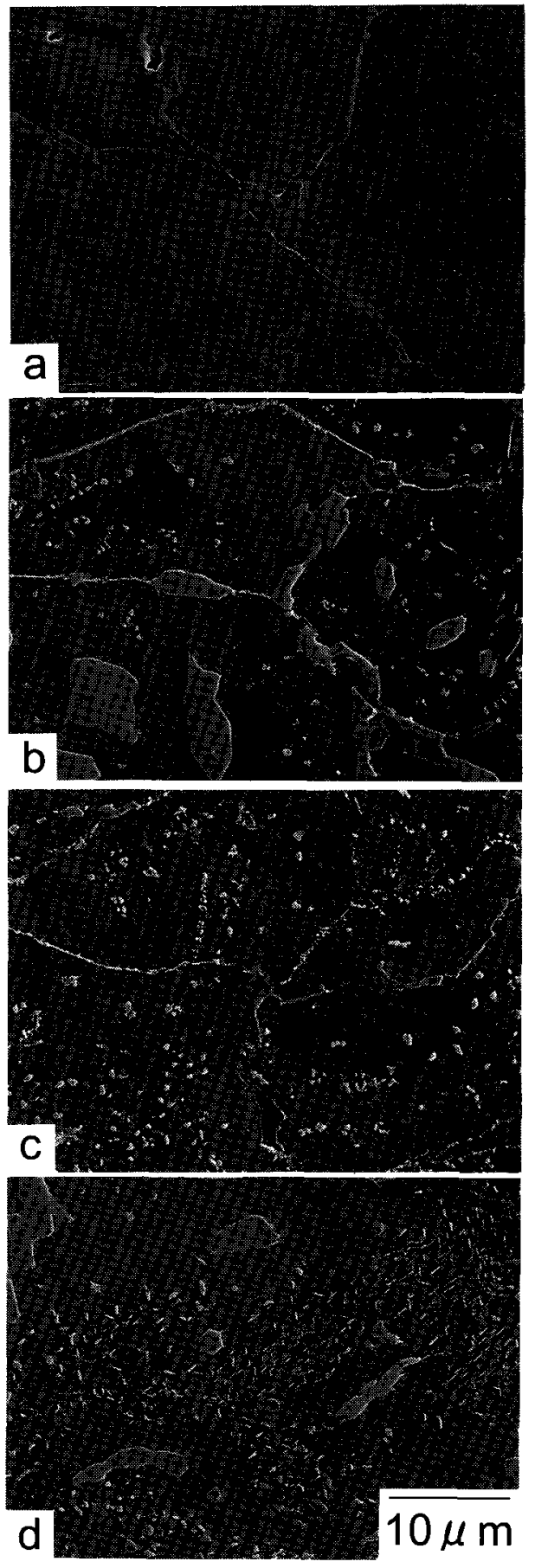
a) $3 \mathrm{~W}-0 \mathrm{Co}, \mathrm{t}_{\mathrm{r}}=36.0 \mathrm{~h}$
b) $6 \mathrm{~W}-0 \mathrm{Co}, \mathrm{t}_{\mathrm{r}}=346.6 \mathrm{~h}$
c) $3 \mathrm{~W}-3 \mathrm{Co}, \mathrm{t}_{\mathrm{r}}=1,111.9 \mathrm{~h}$
d) $6 \mathrm{~W}-3 \mathrm{Co}, \mathrm{t}_{\mathrm{r}}=4,947.6 \mathrm{~h}$

Fig. 8 Secondary electron images of the creep ruptured specimens at $923 \mathrm{~K}-100 \mathrm{MPa}$ of (a) $3 \mathrm{~W}-0 \mathrm{Co}$, (b) $6 \mathrm{~W}-0 \mathrm{Co}$, (c) $3 \mathrm{~W}-3 \mathrm{Co}$ and (d) $6 \mathrm{~W}-3 \mathrm{Co}$ steels.

\section{Conclusions}

Effects of alloying elements of $\mathrm{W}$ and $\mathrm{Co}$ on a creep strength of full annealed $15 \mathrm{Cr}$ ferritic steels of Fe-0.1C-15Cr-1Mo-3W-0.2V-0.05Nb-0.07N-0.003B has been investigated and the following results are obtained.

(1) Decrease in creep rate with precipitation of particles within grain has been observed in the transient creep stage.

(2) Increase in a magnitude of decrease in creep rate in the transient creep stage is obtained by increase in W content.

(3) Decrease in creep rate at the beginning of creep deformation and increase in a magnitude of decrease in creep rate in the transient creep stage are obtained by addition of $\mathrm{Co}$.

(4) Combination of $\mathrm{W}$ and Co decreases a creep rate at the beginning of creep deformation and drastically decreases a creep rate during transient creep stage.

(5) It has been concluded that full annealed $15 \mathrm{Cr}$ ferritic steel strengthened by precipitates is one of the candidate materials for new Ultra Supercritical (USC) power plant in the 21 st century.

\section{REFERENCES}

1) R. Kehlhofer: Materials for Advanced Power Engineering 1998, Proc. 6th Liege Conf., Materials for Advanced Power Engineering 1998, Forschungszentrum Jülich $\mathrm{GmbH}$, Jülich, 1(1998), 3

2) F. Abe, M. Igarashi, N. Fujitsuna, K. Kimura and S. Muneki: Materials for Advanced Power Engineering 1998, Proc. 6th Liege Conf., Materials for Advanced Power Engineering 1998, Forschungszentrum Jülich GmbH, Jülich, 1(1998), 259.

3) F. Masuyama: Materials for Advanced Power Engineering 1998, Proc. 6th Liege Conf., Materials for Advanced Power Engineering 1998, Forschungszentrum Jülich $\mathrm{GmbH}$, Jülich, 3(1998), 1807

4) K. Kimura, H. Kushima, K. Yagi and C. Tanaka: Tetsu-to-Hagené, 77(1991), 667.

5) K. Kimura: Materia Jpn., 35(1996), 535

6) K. Kimura, T. Matsuo, M. Kikuchi and R. Tanaka: Tetsu-to-Hagené, 72(1986), 474.

7) H. Kushima, K. Kimura and F. Abe: Tetst-to-Hagené, 85(1999), 841

8) K. Kimura, H. Kushima and F. Abe: Key Engineering Materials, 171-174(2000), 483

9) K. Kimura, H. Kushima, E. Baba, T. Shimizu, Y. Asai, F. Abe and K. Yagi: Proc. of the 5th International Charles Parsons Turbine Conference, (2000), 558

10) K. Kimura, H. Kushima, E. Baba, T. Shimizu, Y. Asai, F. Abe and K. Yagi: Tetsu-to-Hagené, 86(2000), 542.

11) NRIM Data Sheet on the Elevated-Temperature Properties of $9 \mathrm{Cr}-1 \mathrm{Mo}-\mathrm{V}-\mathrm{Nb}$ Steel Tubes for Boilers and Heat Exchangers and $9 \mathrm{Cr}-1 \mathrm{Mo}-\mathrm{V}-\mathrm{Nb}$ Steel Plates for Boilers and Pressure Vessels, No.43, National Research Institute for Metals (NRIM), Tsukuba, (1996)

12) Data Package for NF616 Ferritic Steel ( $9 \mathrm{Cr}-0.5 \mathrm{Mo}-1.8 \mathrm{~W}-\mathrm{Nb}-$ V), Second Edition, Nippon Steel Corporation, Tokyo, (1994) 